\title{
Comparison of Growth and Alkalinity- induced Responses in Two Cultivars of Hibiscus (Hibiscus rosa-sinensis L.)
}

\author{
Luis Alonso Valdez-Aguilar ${ }^{1}$ and David William Reed ${ }^{2,3}$ \\ Department of Horticultural Sciences, Texas A\&M University, MS 2133, \\ College Station, TX 77843-2133
}

Additional index words. sodium bicarbonate, root zone acidification, water quality, iron efficiency, iron reductase

\begin{abstract}
Response to alkalinity was evaluated in two hibiscus cultivars, Bimini Breeze and Carolina Breeze, grown in a soilless growing medium and in hydroponic culture. For soilless growing medium, plants were potted in a sphagnum peat-perlite-based substrate and irrigated with solutions containing 0 to $10 \mathrm{~mm} \mathrm{NaHCO}_{3}$ for 12 weeks. In hydroponic culture, bare-rooted plants were transferred to a 9-L tray containing a Hoagland's nutrient solution prepared with $\mathrm{NaHCO}_{3}$ at the concentrations previously indicated. In soilless growing medium, shoot dry weight was minimally affected by $\mathrm{NaHCO}_{3}$ concentration for 'Bimini Breeze', but 'Carolina Breeze' exhibited a significant decrease in shoot mass with increasing $\mathrm{NaHCO}_{3}$ concentration. In hydroponic culture, increasing concentration of $\mathrm{NaHCO}_{3}$ induced a decrease in shoot and root mass in both cultivars, but root mass decrease was more pronounced in 'Bimini Breeze'. In soilless growing medium, increasing the concentration of $\mathrm{NaHCO}_{3}$ caused an increase in growing medium $\mathrm{pH}$. The $\mathrm{pH}$ increase was less pronounced for 'Bimini Breeze' than for 'Carolina Breeze', indicating a higher capacity for root zone acidification by 'Bimini Breeze'. Newly developed leaves of both cultivars showed increasing chlorosis with increasing $\mathrm{NaHCO}_{3}$ concentration. However, 'Bimini Breeze' was more tolerant because, according to regression models, $5.7 \mathrm{~mm} \mathrm{NaHCO}_{3}$ would be required to reduce chlorophyll levels by $\mathbf{1 0} \%$, compared with $2.2 \mathrm{~mm}$ for 'Carolina Breeze', when grown in soilless medium. Fe reductase activity decreased when 'Carolina Breeze' plants were grown in 5 mm $\mathrm{NaHCO}_{3}$. However, in 'Bimini Breeze', $\mathrm{Fe}$ reductase activity was enhanced. These observations indicate that the increased tolerance of 'Bimini Breeze' to increasing alkalinity is the result of enhanced Fe reductase activity and increased acidification of the root zone.
\end{abstract}

Alkalinity is a measure of the buffering capacity of an aqueous solution and is the sum of the concentration of soluble alkalis in water. In irrigation water, the main components of alkalinity are $\mathrm{HCO}_{3}^{-}$and $\mathrm{CO}_{3}{ }^{2-}$ (Whipker, 2001). High alkalinity in irrigation water results in increased growing medium $\mathrm{pH}$ resulting from the neutralization of $\mathrm{H}^{+}$by $\mathrm{HCO}_{3}{ }^{-}$and $\mathrm{CO}_{3}{ }^{2-}$. Alkalinity of irrigation water is considered a critical quality parameter because of its direct effect on growing medium solution $\mathrm{pH}$ and its direct and indirect effects on plant growth, quality, and marketability. Alkalinity of water is a severe problem in many areas. In the United States, Argo et al. (1997) reported that only $22 \%$ of

\footnotetext{
Received for publication 23 May 2006. Accepted for publication 27 July 2006.

Grant support was provided from the Texas Ornamental Enhancement Program and The Fred C. Gloeckner Foundation, Inc.

We acknowledge Yoder Brothers Inc. for providing plant material.

${ }^{1}$ CONACYT PhD Fellow. Current address: USDAARS George E. Brown, Jr. Salinity Laboratory, 450 W. Big Springs Road, Riverside, CA 92507-4617. ${ }^{2}$ Professor.

${ }^{3}$ To whom reprint requests should be addressed; e-maildwreed@tamu.edu
}

the waters surveyed contained alkalinity concentrations within the recommended range (40-100 $\left.\mathrm{mg} \cdot \mathrm{L}^{-1}\right)$, and the mean $\left(160 \mathrm{mg} \cdot \mathrm{L}^{-1}\right)$ and median $\left(130 \mathrm{mg} \cdot \mathrm{L}^{-1}\right)$ alkalinity levels were more than the recommended range.

One of the major consequences of high alkalinity, and the resultant $\mathrm{pH}$, is decreased availability of $\mathrm{Fe}$ for plant acquisition. The most evident responses of plants to high alkalinity are interveinal chlorosis in the youngest leaves and stunted growth (Lucena, 2000; Pearce et al., 1999a,b), which have been attributed to $\mathrm{Fe}$ deficiency resulting from decreased Fe uptake (Bertoni et al., 1992, McCallister et al., 1989) or Fe availability. At high $\mathrm{pH}$ values, $\mathrm{Fe}$ is in the form of hydroxides or other insoluble compounds Leaf chlorosis also may be the result of tissue Fe not being available or inactive (Marschner, 1995). In hydroponic culture, $\mathrm{HCO}_{3}^{-}$has been demonstrated to inhibit $\mathrm{Fe}$ utilization, inducing chlorosis (Fleming et al., 1984). Plants have developed mechanisms to overcome alkalinity-induced Fe deficiency. These include increased $\mathrm{Fe}$ reductase capacity, net extrusion of $\mathrm{H}^{+}$, release of phenolic compounds or phytosiderophores to act as $\mathrm{Fe}^{3+}$ chelators, and formation of proteoid roots with a high reductase activity and high capacity to release $\mathrm{H}^{+}$(Marschner, 1995).
Most studies on the effect of alkalinity on the performance of greenhouse ornamental plants have been carried out on plants cultivated in a soilless growing medium. The buffering capacity of artificial growing media often causes an increase in $\mathrm{pH}$ to occur slowly, as a result of alkalinity. Thus, newly transplanted plants may grow under a nondetrimental growing medium $\mathrm{pH}$ for at least some weeks, as reported for impatiens by Argo and Biernbaum (1996). For this reason, to determine the direct and immediate response of plants to alkalinity, it would be desirable to use hydroponic culture.

Valdez-Aguilar and Reed (2007) screened several greenhouse crops for response to alkalinity in irrigation water. Two cultivars of hibiscus exhibited differential alkalinity tolerance. Based on growth and leaf chlorosis, 'Bimini Breeze' was more tolerant than 'Mango Breeze.' The objectives of this study were to compare the growth responses of one tolerant and one susceptible hibiscus cultivar grown in both soilless growing medium and hydroponic culture, and to determine the role of Fe reductase and increased proton extrusion as mechanisms of tolerance to alkalinity.

\section{Materials and Methods}

Determination of tolerance to alkalinity in plants grown in sphagnum peat-perlitebased soilless growing medium. Hibiscus 'Bimini Breeze' and 'Carolina Breeze' (Yoder Brothers, Salinas, Calif.; substituted for 'Mango Breeze') liners were transplanted on 2 Nov. 2000 into 10.2-cm-diameter standard pots containing Sunshine \#2 sphagnum peatperlite mix (Sun Gro Horticulture, Bellevue, Wash.), a commercial soilless growing medium adjusted to $\mathrm{pH} 6.3$ with lime. The soilless growing medium was preplant amended with $4.7 \mathrm{~kg} \cdot \mathrm{m}^{-3}$ 14-14-14 Osmo$\operatorname{cote}^{\circledR}$ (Scotts Sierra, Marysville, Ohio) and 1 $\mathrm{kg} \cdot \mathrm{m}^{-3}$ Micromax trace element mix (Scotts Sierra). The experiment was conducted in a glass greenhouse, and the average photosynthetically active radiation, temperature, and relative humidity were $354 \pm 26$ $\mu \mathrm{mol} \cdot \mathrm{m}^{-2} \cdot \mathrm{s}^{-1}$ noontime, $25 / 13{ }^{\circ} \mathrm{C}$ day/night, and $65 \%$ respectively. The plants were allowed to establish for 1 week and treatments started on 9 Nov. 2000. A 0.5 to $1-\mathrm{cm}$ soft pinch was carried out 1 week after treatments started. The experimental design was a single factorial completely randomized design with five replications; one pot containing one plant constituted a replication. The five alkalinity treatments were $0,2.5,5,7.5$, and $10 \mathrm{~mm}$ $\mathrm{NaHCO}_{3}\left(0,153,305,458\right.$, and $610 \mathrm{mg} \cdot \mathrm{L}^{-1}$ $\mathrm{HCO}_{3}{ }^{-}$) prepared with reverse osmosis-deionized purified water. Solutions were prepared $24 \mathrm{~h}$ before use to allow $\mathrm{pH}$ stabilization, under ambient conditions, and the corresponding treatment solution $\mathrm{pH}$ values were $5.61 \pm 0.14,8.28 \pm 0.07,8.51 \pm$ $0.09,8.61 \pm 0.09$, and $8.65 \pm 0.05(\mathrm{pH} \pm \mathrm{sE}, \mathrm{n}$ $=5$ ) respectively. Plants were top watered as needed by hand to achieve a leaching fraction 
between 0.2 and 0.3 . On irrigation day, a plant from each treatment was randomly selected and the volume of irrigation water needed was determined by adding small increments of the respective solutions until a leaching fraction of 0.2 to 0.3 was achieved.

The experiment was ended on 9 Feb. 2001 (day 92). The parameters measured were chlorophyll concentration (as determined by the SPAD index) of newly formed leaves, shoot and root dry weight, and growing medium $\mathrm{pH}$. The SPAD index was determined with a model 501 SPAD meter (Minolta Camera Co., Ltd., Osaka, Japan). Root dry weight was determined by separating the container medium into three horizontal layers: top, middle, and bottom third. Roots were separated from the growing medium under running water, blotted dry, and dried in an oven at $75{ }^{\circ} \mathrm{C}$ for $72 \mathrm{~h}$ before dry weight determination. Samples of growing medium from each layer were collected to determine growing medium $\mathrm{pH}$. The growing medium was thoroughly mixed with nanopure water in a $1: 2$ proportion $(30 \mathrm{~mL}$ growing medium: $60 \mathrm{~mL}$ water), allowed to sit for $60 \mathrm{~min}$, and then filtered. The filtrate $\mathrm{pH}$ and electrical conductivity (EC) were determined with a Twin $\mathrm{pH}$ meter (Spectrum Technologies, Plainfield, Ill.) and EC meter (model B-173; HORIBA Ltd., Kyoto, Japan). For shoot dry weight determination, plants were cut at the growing medium surface, placed in individual paper bags, dried in an oven at $75{ }^{\circ} \mathrm{C}$ for $72 \mathrm{~h}$, and then weighed.

Data were analyzed by analysis of variance (ANOVA; SAS Institute, Cary, N.C.) and regression analysis to determine linear, quadratic, and cubic regression models. The best fit regression model selected was the simplest significant model with the highest $R^{2}$ value and a nonsignificant lack of fit. Subsequently, the best fit model was used to estimate the $\mathrm{NaHCO}_{3}$ concentration yielding a $10 \%, 20 \%$, and $30 \%$ decrease in SPAD index, and shoot and root dry weight compared with the $0 \mathrm{~mm} \mathrm{NaHCO} 3$ controls.

Growth responses and $\mathrm{Fe}$ reductase activity in hibiscus plants grown in hydroponic culture under high alkalinity. Hibiscus liners were grown in aerated hydroponic solutions in a controlled environment growth room (model M96-10-5K-0750A277/480; Environmental Growth Chambers, Chagrin Falls, Ohio). Temperature was set at $27 / 16{ }^{\circ} \mathrm{C}$ day/night, average relative humidity was $60 \%$, and average photosynthetically active radiation was $480 \mu \mathrm{mol} \cdot \mathrm{m}^{-2} \cdot \mathrm{s}^{-1}$. Day length was 0700 to $1900 \mathrm{HR}$.

Individual 10 to $12.5-\mathrm{cm}$ liners (Yoder Brothers, Salinas, Calif.) were transplanted on 3 Nov. 2000, and plants were harvested on 14 Dec. 2000 (day 41). Five plants of each cultivar were inserted into Styrofoam floats in 9-L plastic containers containing the respective nutrient solutions. Filtered air was bubbled constantly in the nutrient solution of each container. Containers were covered with a bicolor plastic sheet (black inside, white top) to prevent light from reaching nutrient solutions. Treatments started as soon as plants were transferred to the containers.

The complete nutrient solution contained $15 \mathrm{~mm} \mathrm{~N}\left(80 \% \mathrm{NO}_{3}{ }^{-} \mathrm{N}\right.$ and $\left.20 \% \mathrm{NH}_{4}{ }^{+} \mathrm{N}\right), 1$ mм P, 6 mм K, 4.5 mм Ca, 2 mм Mg, 4.5 mм $\mathrm{S}, 5 \mathrm{mg} \cdot \mathrm{L}^{-1} \mathrm{Fe}$ as $\mathrm{Fe}$-diethylenetriamine pentaacetate (Fe-DTPA), $0.02 \mathrm{mg} \cdot \mathrm{L}^{-1} \mathrm{Cu}$, $0.5 \mathrm{mg} \cdot \mathrm{L}^{-1} \mathrm{~B}, 0.11 \mathrm{mg} \cdot \mathrm{L}^{-1} \mathrm{Mo}$, and 0.65 $\mathrm{mg} \cdot \mathrm{L}^{-1} \mathrm{Mn}$. The solutions were prepared with nanopure water and $\mathrm{Ca}\left(\mathrm{NO}_{3}\right)_{2} \cdot 4 \mathrm{H}_{2} \mathrm{O}$, $\left(\mathrm{NH}_{4}\right)_{2} \mathrm{SO}_{4}, \mathrm{KNO}_{3}, \mathrm{CaSO}_{4} \cdot 2 \mathrm{H}_{2} \mathrm{O}, \mathrm{KH}_{2} \mathrm{PO}_{4}$, $\mathrm{MgSO}_{4} \cdot 7 \mathrm{H}_{2} \mathrm{O}$, Fe-DTPA, $\mathrm{CuSO}_{4} \cdot 5 \mathrm{H}_{2} \mathrm{O}$, $\mathrm{ZnSO}_{4} \cdot 5 \mathrm{H}_{2} \mathrm{O},\left(\mathrm{NH}_{4}\right)_{6} \mathrm{Mo}_{7} \mathrm{O}_{24} \cdot 4 \mathrm{H}_{2} \mathrm{O}$, $\mathrm{MnSO}_{4} \cdot \mathrm{H}_{2} \mathrm{O}$, and $\mathrm{H}_{3} \mathrm{BO}_{3}$. The concentrations of $\mathrm{NaHCO}_{3}$ treatments were $0,2.5,5$, 7.5 , and $10 \mathrm{~mm}$. The $\mathrm{pH}$ of the solutions was $6.14 \pm 0.02,7.93 \pm 0.02,8.39 \pm 0.04,8.53 \pm$ 0.05 , and $8.66 \pm 0.03(\mathrm{pH} \pm \mathrm{SE}, \mathrm{n}=5)$ respectively, and $\mathrm{EC}$ was $2.50 \pm 0.1 \mathrm{dS} \cdot \mathrm{m}^{-1}$, $2.45 \pm 0.2 \mathrm{dS} \cdot \mathrm{m}^{-1}, 2.65 \pm 0.1 \mathrm{dS} \cdot \mathrm{m}^{-1}, 2.70 \pm$ $0.2 \mathrm{dS} \cdot \mathrm{m}^{-1}$, and $2.80 \pm 0.2 \mathrm{dS} \cdot \mathrm{m}^{-1}(\mathrm{EC} \pm \mathrm{sE}$, $\mathrm{n}=5$ ) respectively. It should be noted that even though an iron chelate (Fe-DTPA) was used in the hydroponic solutions, alkalinityinduced iron stress can still occur in the higher $\mathrm{pH}$ solutions (Marschner, 1995). Nutrient solutions were maintained at the original volume in the containers with nanopure water and were changed every 2 weeks.

The parameters measured were SPAD index, shoot dry weight, root dry weight, root diameter, root length, root surface area, and Fe reductase activity. The SPAD index and shoot and root dry weight were measured as indicated in the previous experiment. Harvested roots were scanned and the image analyzed using WinRHIZO v4.1b (Reagent Instruments, Quebec) to determine root diameter, length, and surface area.

The Fe reductase assay was performed on entire root systems according to Lang et al. (1990) and Rosenfield et al. (1991). The intact root system from each treatment was immersed in $250 \mathrm{~mL}$ of a continuously aerated $\mathrm{pH} 5.5$ buffer solution consisting of 0.1 mM Fe-ethylenediamine tetraacetic acid $(\mathrm{Fe}-$ EDTA), 5 mм 2-[N-morpholino]ethanesulfonic acid (MES), $0.5 \mathrm{~mm} \mathrm{CaSO}_{4}$, and 0.3 mм 4,7-diphenyl-1, 10-phenantrolinedisulfonic acid (BPDS). The glass assay containers were painted black to prevent light from reaching the solution. The reaction was carried out at $21{ }^{\circ} \mathrm{C}$ and under greatly reduced light to avoid photoreduction. After $60 \mathrm{~min}$, a sample of the solution was withdrawn and its absorbance was measured (spectrophotometer model 21; Bausch and Lomb, Rochester, N.Y.) at $535 \mathrm{~nm}$. The readings were compared

Table 1. Analysis of variance of shoot dry weight, root dry weight, SPAD index, and growing medium $\mathrm{pH}$ of two cultivars of hibiscus grown in soilless growing medium in response to increasing concentrations of $\mathrm{NaHCO}_{3}$.

\begin{tabular}{|c|c|c|c|c|c|c|}
\hline & \multirow{2}{*}{$\begin{array}{l}\text { Shoot dry } \\
\text { weight }(\mathrm{g})\end{array}$} & \multirow{2}{*}{$\begin{array}{c}\text { Root dry } \\
\text { weight (g) }\end{array}$} & \multirow{2}{*}{$\begin{array}{l}\text { SPAD } \\
\text { index }\end{array}$} & \multicolumn{3}{|c|}{ Growing medium $\mathrm{pH}$} \\
\hline & & & & Top layer & Middle layer & Bottom layer \\
\hline \multicolumn{7}{|l|}{$\overline{\mathrm{ANOVA}}$} \\
\hline Cultivar & $*$ & NS & $* * *$ & NS & $* * *$ & $* * *$ \\
\hline $\mathrm{NaHCO}_{3}$ & $* * *$ & $* * *$ & $* * *$ & $* * *$ & $* * *$ & $* * *$ \\
\hline Interaction & NS & NS & $* *$ & NS & NS & NS \\
\hline$R^{2}$ & 0.53 & 0.71 & 0.90 & 0.97 & 0.97 & 0.98 \\
\hline
\end{tabular}

with a standard curve prepared with $\mathrm{Fe}^{2+}$, and the data were expressed as micrograms of iron per gram root dry weight per hour.

Data were analyzed using ANOVA (SAS Institute) and regression analysis to produce linear, quadratic, and cubic regression models.

\section{Results and Discussion}

Shoot dry weight. A significant cultivar and $\mathrm{NaHCO}_{3}$ concentration effect on shoot dry weight was detected in plants grown in soilless medium (Table 1). The response of shoot dry weight in 'Carolina Breeze' grown in soilless growing medium best fit a quadratic model, with a slight beneficial effect at low $\mathrm{NaHCO}_{3}$ concentration and a significant decrease at higher concentrations of $\mathrm{NaHCO}_{3}$ (Fig. 1A). The increased sensitivity to high concentrations of $\mathrm{NaHCO}_{3}$ and the beneficial effect of a low concentration in hibiscus 'Carolina Breeze' is similar to the response exhibited by hibiscus 'Mango Breeze' in previous studies (Valdez-Aguilar and Reed, 2007). The response of shoot dry weight in 'Bimini Breeze' best fit a quadratic model, with only a moderate decrease in shoot dry weight with increased $\mathrm{NaHCO}_{3}$ concentration. This greater tolerance of 'Bimini Breeze' to $\mathrm{NaHCO}_{3}$ is similar to previous studies (Valdez-Aguilar and Reed, 2007). The predicted $10 \%, 20 \%$, and $30 \%$ decrease in shoot dry weight, according to the best fit models, was at 6.6, 8.4, and $9.8 \mathrm{~mm} \mathrm{NaHCO}_{3}$ for 'Carolina Breeze' respectively, and was at 7.9, 14.1, and $19.4 \mathrm{~mm} \mathrm{NaHCO}_{3}$ for 'Bimini Breeze' respectively. Thus, at higher concentrations, 'Bimini Breeze' exhibited much greater tolerance, relative to shoot dry weight, to $\mathrm{NaHCO}_{3}$ concentration.

A significant cultivar and $\mathrm{NaHCO}_{3}$ concentration effect on shoot dry weight was detected in plants grown in hydroponic culture (Table 2). The best fit models were linear, with a steep slope for both cultivars, indicating that high concentrations of $\mathrm{NaH}-$ $\mathrm{CO}_{3}$ induced a severe decrease in shoot growth (Fig. 2A). In hydroponic culture, where exposure to alkalinity was direct and immediate, 'Bimini Breeze' did not exhibit greater tolerance to increasing $\mathrm{NaHCO}_{3}$ concentrations. The greater tolerance of 'Bimini Breeze' to higher $\mathrm{NaHCO}_{3}$ concentrations demonstrated in the peat-perlite growing medium (Fig. 1A) was not evident in hydroponic culture (Fig. 2A).

With regard to the peat-perlite growing medium, other studies reported that irrigating 

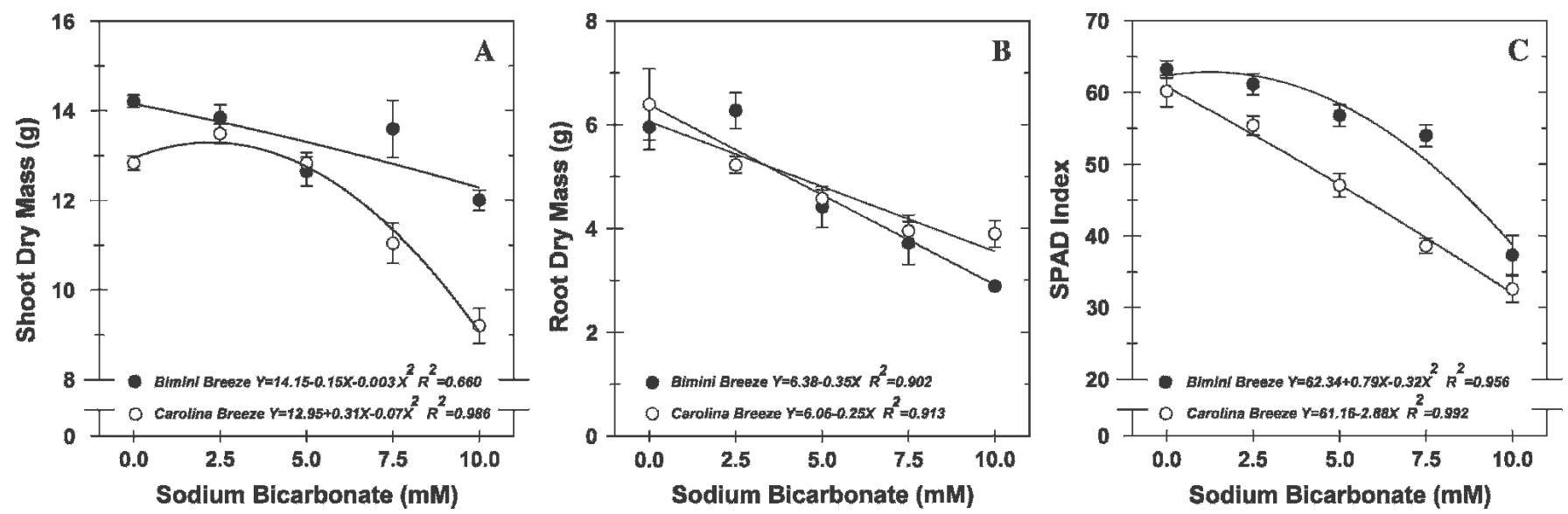

Fig. 1. (A-C) Effect of increasing concentrations of $\mathrm{NaHCO}_{3}$ in irrigation water on shoot dry weight (A), root dry weight (B), and SPAD index (C) of hibiscus 'Bimini Breeze' and 'Carolina Breeze' grown in soilless growing media. Bars represent SE $(\mathrm{n}=5)$.

impatiens with water containing $320 \mathrm{mg} \cdot \mathrm{L}^{-1}$ of alkalinity (as $\mathrm{CaCO}_{3}$ ) only caused a measurable increase in growing medium $\mathrm{pH}$ after 4 weeks, and reached its maximum level $(\mathrm{pH}$ 8.5) in 8 weeks (Argo and Biernbaum, 1996). Thus, there is a period of time in peat-based growing media when plants are exposed to a nondetrimental $\mathrm{pH}$ level even though they are being irrigated with water of high alkalinity. It is possible that the buffering capacity of the limed sphagnum peat moss-perlitebased medium used for the current experiment allowed enough time for both cultivars to establish a larger functional root systems. This might allow 'Bimini Breeze' to elicit strategies of alkalinity tolerance in soilless growing media that are not possible in hydroponic culture, which will be addressed later.

Root mass and growth. Root dry weight of both hibiscus cultivars was affected by high alkalinity in plants grown in soilless medium (Table 1) and in hydroponic culture (Table 2 ). In soilless medium, the decrease in root dry weight was similar in both cultivars (Fig. $1 \mathrm{~B})$, which is verified by a nonsignificant cultivar $\times \mathrm{NaHCO}_{3}$ interaction (Table 1). In hydroponic culture, the decrease in root mass exhibited by 'Bimini Breeze' had a greater slope compared with 'Carolina Breeze', indicating a higher sensitivity of the root system of 'Bimini Breeze' (Fig. 2B). This is verified by a significant cultivar $\times \mathrm{NaHCO}_{3}$ interaction (Table 2). Thus, the root systems of both cultivars were highly sensitive to indirect (in soilless growing medium) and direct (in hydroponic culture) effects of $\mathrm{NaHCO}_{3}$.

Table 2. Analysis of variance of shoot and root dry weight, SPAD index, and Fe reductase activity of two cultivars of hibiscus grown in hydroponic culture in response to increasing concentrations of $\mathrm{NaHCO}_{3}$ in nutrient solution.

\begin{tabular}{lcccc}
\hline & $\begin{array}{c}\text { Shoot dry weight } \\
(\mathrm{g})\end{array}$ & $\begin{array}{c}\text { Root dry weight } \\
(\mathrm{g})\end{array}$ & $\begin{array}{c}\text { SPAD } \\
\text { index }\end{array}$ & $\begin{array}{c}\text { Fe reductase activity } \\
\left(\mu \mathrm{g} \mathrm{Fe}^{3+} \cdot \mathrm{g}^{-1} \mathrm{dry} \mathrm{wt}^{-1}\right)\end{array}$ \\
\hline ANOVA & $* * *$ & $* * *$ & $* * *$ & $* * *$ \\
Cultivar & $* * *$ & $* * *$ & $* * *$ & $* * *$ \\
$\mathrm{NaHCO}_{3}$ & $\mathrm{NS}$ & $* * *$ & $*$ & $* * *$ \\
Interaction & 0.95 & 0.96 & 0.89 & 0.95 \\
$R^{2}$ & NS,**** Nonsignificant or significant at $P<0.05$ and $<0.001$ respectively.
\end{tabular}

In hydroponic culture, increasing levels of alkalinity caused a significant decrease in total root length and surface area in both cultivars (Table 3 ). The cultivar $\times \mathrm{NaHCO}_{3}$ interaction was significant, indicating that cultivars responded differently to increasing alkalinity. Root diameter remained unaffected in 'Bimini Breeze', but in 'Carolina Breeze' there was a $34 \%$ increase at $10 \mathrm{~mm}$ $\mathrm{NaHCO}_{3}$ compared with the control plants. Similar results were reported in Lupinus angustifolius, where root growth was inhibited by high $\mathrm{pH}$ resulting from a decrease in cell elongation, leading to increased root diameter (Marschner, 1995). An increase in root tip diameter has been reported for plants growing under $\mathrm{Fe}$ deficiency conditions, which is associated with an enhanced $\mathrm{H}^{+}$ extrusion confined to the swollen tips (Dell'Orto et al., 2002; Zouari et al., 2001). Increased root diameter in maize, sorghum, and barley has been reported when grown in solutions containing a high concentration of $\mathrm{HCO}_{3}{ }^{-}$(Alhendawi et al., 1997). The alterations in root morphology may be the result of increased synthesis of ethylene (Schikora and Schmidt, 2002) and auxins (Schikora and Schmidt, 2002; Schmidt et al., 2000). In the current study, we report the average diameter of roots, not discriminating between tips or any other portion of the roots.

These observations indicate that the greater tolerance of 'Bimini Breeze' to higher $\mathrm{NaHCO}_{3}$ concentrations, based on shoot dry weight (Fig. 1A), was not the result of quantitative growth parameters of the root system (Figs. 1B and 2B, Table 2). Other qualitative or physiological factors must be involved.

Growing medium EC. The highest EC readings were obtained in the bottom layer of the growing medium in all treatments, with the following values: $1.16 \pm 0.10,1.34 \pm$ $0.20,1.31 \pm 0.12,1.21 \pm 0.13$, and $1.08 \pm$ $0.10 \mathrm{dS} \cdot \mathrm{m}^{-1}$ for the $0,2.5,5,7.5$, and $10 \mathrm{~mm}$ $\mathrm{NaHCO}_{3}$ treatments respectively. All these EC readings are within the range or less than the recommended maximum EC of 1.2 to $1.5 \mathrm{dS} \cdot \mathrm{m}^{-1}$ for established plants (Lang, 1996; Warncke and Krauskopf, 1983). Therefore, high growing medium EC levels were not a contributing factor to the plant responses observed.

Growing medium $p H$. The growing medium $\mathrm{pH}$ was significantly altered by the $\mathrm{NaHCO}_{3}$ concentration in irrigation water in all three layers (Table 1). There also was a significant cultivar effect, indicating that the two cultivars affected the $\mathrm{pH}$ of the growing medium differently.

Both cultivars acidified the growing medium in the control treatment $(0 \mathrm{~mm} \mathrm{NaH}$ $\mathrm{CO}_{3}$ ) by 0.7 to $1.5 \mathrm{pH}$ units, depending on the cultivar and growing medium layer (Fig. 3 ). As the concentration of $\mathrm{NaHCO}_{3}$ increased, only 'Bimini Breeze' roots in the bottom layer were able to acidify the growing medium enough to counteract even the lowest concentration of $\mathrm{NaHCO}_{3}$ tested $(2.5 \mathrm{~mm}$, Fig. $3 \mathrm{C})$. In the bottom layer, where most of the roots occur, 'Bimini Breeze' maintained a $\mathrm{pH}$ 0.5 to 1.0 units lower than 'Carolina Breeze'. The greater acidification by 'Bimini Breeze' became most evident at higher $\mathrm{NaHCO}_{3}$ concentrations (Fig. 3C), despite a significant decrease in root mass (50\%; Fig. 1B), total root length $(79 \%)$, and root surface area $(80 \%$; Table 3$)$. This indicates a qualitative change in the root system of 'Bimini Breeze' with increasing alkalinity. Increased acidification of the rhizosphere is correlated to enhanced synthesis and activity of the $\mathrm{H}^{+}$ATPase in the plasmalemma of root cells (Dell'Orto et al., 2002; Rabotii and Zocchi, 1994) when plants are Fe deficient. Acidification of the rhizosphere may also be the result of the extrusion of $\mathrm{H}^{+}$coupled with 

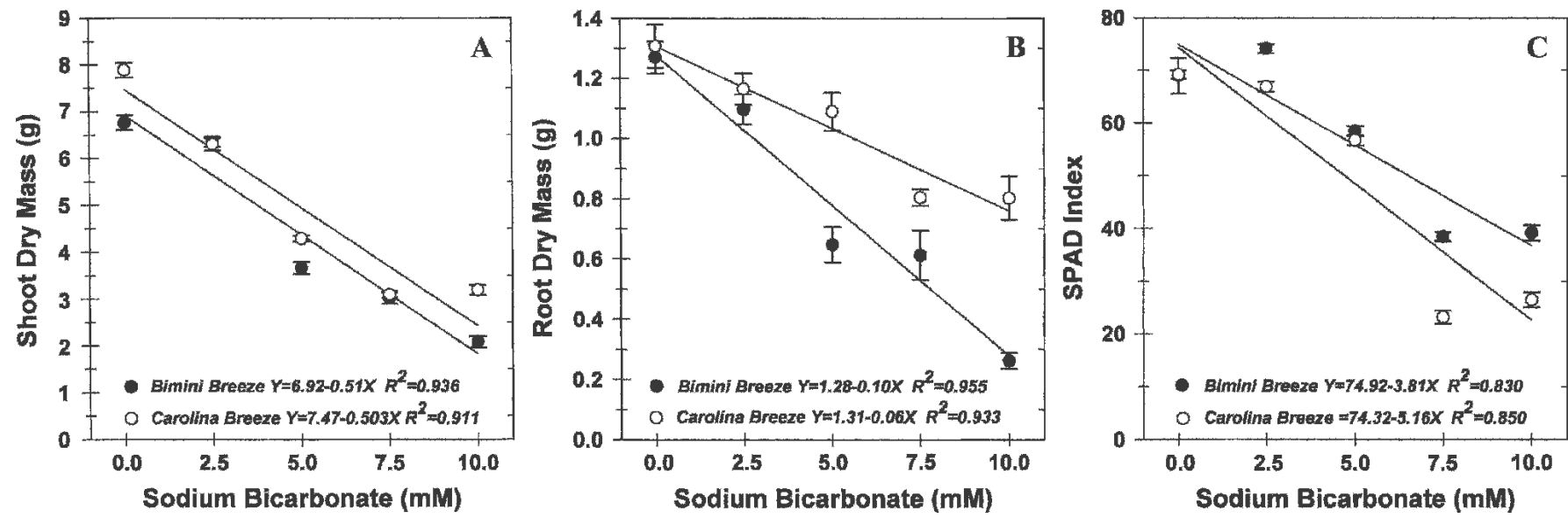

Fig. 2. (A-C) Effect of increasing concentrations of $\mathrm{NaHCO}_{3}$ in nutrient solution on shoot dry weight (A), root dry weight (B), and SPAD index (C) of hibiscus 'Bimini Breeze' and 'Carolina Breeze' grown in hydroponic culture. Bars represent SE $(n=5)$.

Table 3. Effect of increasing concentrations of $\mathrm{NaHCO}_{3}$ in nutrient solution on root growth parameters of two cultivars of hibiscus grown in hydroponic culture.

\begin{tabular}{|c|c|c|c|c|c|c|}
\hline \multirow[b]{3}{*}{$\mathrm{NaHCO}_{3}(\mathrm{mM})$} & \multicolumn{2}{|c|}{ Root length (cm) } & \multicolumn{2}{|c|}{$\begin{array}{l}\text { Root surface } \\
\text { area }\left(\mathrm{mm}^{2}\right)\end{array}$} & \multicolumn{2}{|c|}{ Root diameter $(\mathrm{mm})$} \\
\hline & $\overline{\text { Bimini }}$ & Carolina & $\overline{\text { Bimini }}$ & Carolina & Bimini & Carolina \\
\hline & Breeze $^{z}$ & Breeze & Breeze & Breeze & Breeze & Breeze \\
\hline 0 & $2646 \mathrm{a}$ & $1950 \mathrm{a}$ & $615 \mathrm{a}$ & $600 \mathrm{a}$ & 0.71 & $0.99 \mathrm{c}$ \\
\hline 2.5 & $2269 \mathrm{a}$ & $1477 \mathrm{~b}$ & $522 \mathrm{a}$ & $520 \mathrm{ab}$ & 0.74 & $1.14 \mathrm{bc}$ \\
\hline 5 & $1318 \mathrm{~b}$ & $1132 \mathrm{~b}$ & $317 \mathrm{~b}$ & $443 \mathrm{~b}$ & 0.75 & $1.24 \mathrm{~b}$ \\
\hline 7.5 & $1160 \mathrm{bc}$ & $655 c$ & $303 \mathrm{~b}$ & $290 \mathrm{c}$ & 0.82 & $1.49 \mathrm{a}$ \\
\hline 10 & $564 \mathrm{c}$ & $642 \mathrm{c}$ & $131 \mathrm{c}$ & $276 \mathrm{c}$ & 0.76 & $1.33 \mathrm{ab}$ \\
\hline \multicolumn{7}{|l|}{ ANOVA $^{y}$} \\
\hline Cultivar & \multicolumn{2}{|c|}{$* * *$} & \multicolumn{2}{|c|}{$* * *$} & \multicolumn{2}{|c|}{$* * *$} \\
\hline $\mathrm{NaHCO}_{3}$ & \multicolumn{2}{|c|}{$* * *$} & \multicolumn{2}{|c|}{$* * *$} & \multicolumn{2}{|c|}{$* * *$} \\
\hline Interaction & \multicolumn{2}{|c|}{$* * *$} & \multicolumn{2}{|c|}{$* * *$} & \multicolumn{2}{|c|}{$* * *$} \\
\hline
\end{tabular}

${ }^{\mathrm{z}}$ Within columns, means followed by the same letter indicates a nonsignificant difference at $P<0.05$. *** Significant at $P<0.001$

$\mathrm{NH}_{4}{ }^{+}$uptake (Marschner, 1995) or $\mathrm{NH}_{4}{ }^{+}$ nitrification (Havlin et al., 1999). The higher acidification exhibited by 'Bimini Breeze' is a characteristic of Fe-efficient plants (Marschner, 1995).

Iron Reductase activity. In Fe-efficient plants, the activity of $\mathrm{Fe}$ reductase increases in response to Fe deficiency ( $\mathrm{Li}$ et al., 2000; Zouari et al., 2001). Conditions such as high alkalinity in water result in increased grow- ing medium $\mathrm{pH}$, which in turn results in the formation of insoluble $\mathrm{Fe}$. For this reason, $\mathrm{Fe}$ efficient plants exhibit increased Fe reductase activity when exposed to Fe deficiency or an alkalinity-induced decrease in Fe availability. $\mathrm{Fe}$ reductase activity was significantly affected by both cultivars and $\mathrm{NaHCO}_{3}$ concentration in the nutrient solution (Table 2). In 'Carolina Breeze', $\mathrm{Fe}$ reductase activity decreased as the concentration of $\mathrm{NaHCO}_{3}$ increased, but in 'Bimini Breeze' the $\mathrm{Fe}$ reductase activity increased as $\mathrm{NaHCO}_{3}$ concentration increased (Fig. 4). There was greatly enhanced $\mathrm{Fe}$ reductase activity at 10 mм $\mathrm{NaHCO}_{3}$ in 'Bimini Breeze', up to threefold the activity of control plants. This type of response is characteristic of Fe-efficient plants. Enhancement of root Fe reductase activity may be another mechanism explaining the increased tolerance of hibiscus 'Bimini Breeze' to high $\mathrm{NaHCO}_{3}$ concentrations.

Chlorophyll concentration. Leaves showed increased chlorosis with increasing concentrations of $\mathrm{NaHCO}_{3}$. As indicated by SPAD index measurements, chlorophyll concentration decreased significantly with increasing concentrations of $\mathrm{NaHCO}_{3}$ in plants grown in both soilless medium (Table 1, Fig. 1C) and in hydroponic culture (Table 2, Fig. 2C). For soilless growing medium, the predicted $10 \%, 20 \%$, and $30 \%$ decrease in leaf chlorophyll concentration (as indicated by SPAD readings), according to the best fit models, was at 2.2, 4.5, and $6.6 \mathrm{~mm} \mathrm{NaHCO}_{3}$ for 'Carolina Breeze' respectively, and was at $5.7,7.6$, and $9.0 \mathrm{~mm} \mathrm{NaHCO}_{3}$ for 'Bimini Breeze' respectively. In plants grown in hydroponic culture, similar trends were
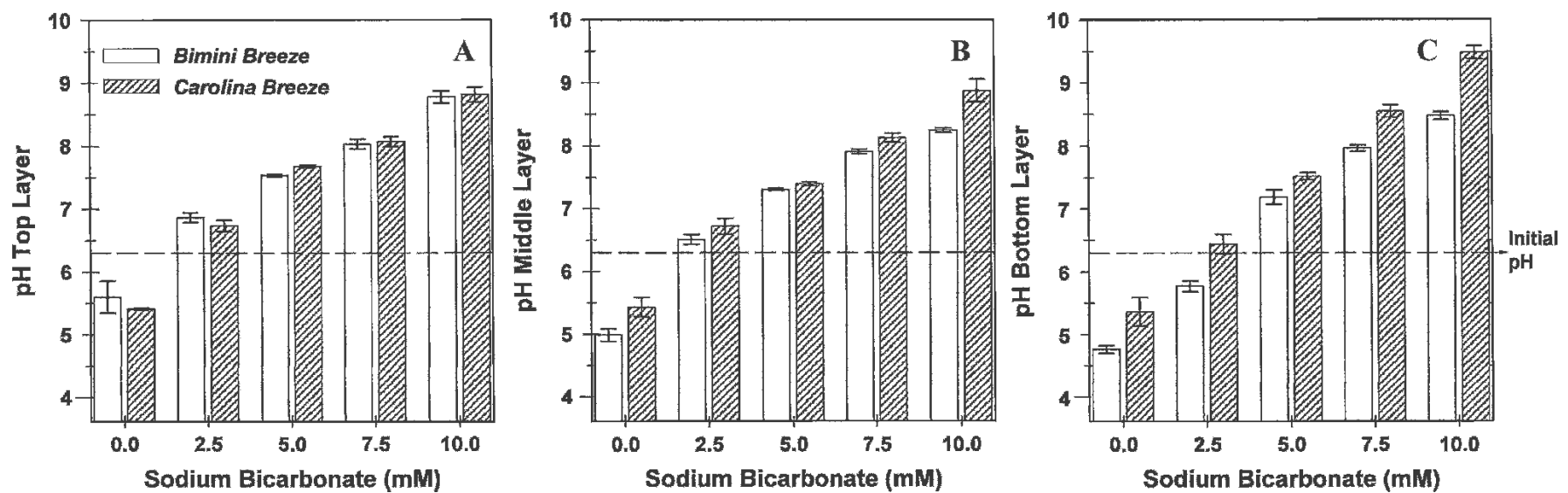

Fig. 3. (A-C) Effect of increasing concentrations of $\mathrm{NaHCO}_{3}$ in irrigation water on $\mathrm{pH}$ in the top (A), middle (B), and bottom $(\mathbf{C})$ container layers for hibiscus 'Bimini Breeze' and 'Carolina Breeze' grown in soilless growing media. Bars represent SE $(n=5)$. 


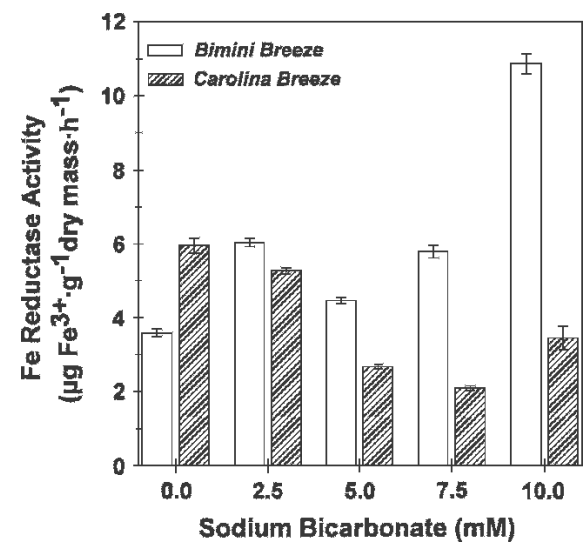

Fig. 4. Effect of increasing concentrations of $\mathrm{NaHCO}_{3}$ in nutrient solution on Fe reductase activity of intact root systems of hibiscus 'Bimini Breeze' and 'Carolina Breeze' grown in hydroponic culture. Bars represent SE $(n=5)$.

observed (Fig. 2C). The increased tolerance of 'Bimini Breeze' is also verified by the significant cultivar $\times \mathrm{NaHCO}_{3}$ interaction in plants grown in both soilless medium (Table 1) and in hydroponic culture (Table 2). The maintenance of higher leaf chlorophyll concentrations in 'Bimini Breeze' is probably the result of enhanced $\mathrm{Fe}$ reductase activity and $\mathrm{Fe}$ acquisition by the root systems (Fig. 4).

In summary, compared with 'Carolina Breeze', 'Bimini Breeze' was able to maintain higher shoot dry weight and lower leaf chlorosis as $\mathrm{NaHCO}_{3}$ concentration increased. This response was associated with the higher capacity of 'Bimini Breeze' to acidify the root zone (Fig. 3C), which allows greater $\mathrm{Fe}$ availability for plant uptake, and the enhancement of $\mathrm{Fe}$ reductase activity (Fig. 4), which allows increased root absorption of $\mathrm{Fe}$. These responses indicate that 'Bimini Breeze' exhibits characteristics of Fe-efficient plants. These data also indicate that $\mathrm{Fe}$ efficiency exists within hibiscus cultivars, which should allow for selection of cultivars adapted to alkaline soils and irrigation water.

The experimental design tested the response of hibiscus to increasing $\mathrm{NaHCO}_{3}$ concentrations. The responses reported herein could be the result of either the in- direct effect of alkalinity-induced $\mathrm{pH}$ increases or increased salinity resulting from either $\mathrm{Na}^{+}$or $\mathrm{HCO}^{-}$, and the experimental design does not allow differentiation between the two. However, the chlorosis and $\mathrm{Fe}$ reductase activity responses reported herein are classic plant responses to increased $\mathrm{pH}$ (Marschner, 1995), which indicates that the differential responses between the two hibiscus cultivars are primarily the result of alkalinity-induced increased $\mathrm{pH}$.

\section{Literature Cited}

Alhendawi, R.A., V. Römheld, E.A. Kirkby, and H. Marschner. 1997. Influence of increasing bicarbonate concentrations on plant growth, organic acid accumulation in roots and iron uptake by barley, sorghum and maize. J. Plant Nutr. 20:1731-1753.

Argo, W.R. and J.A. Biernbaum. 1996. The effect of lime, irrigation-water source, and watersoluble fertilizer on root-zone $\mathrm{pH}$, electrical conductivity, and micronutrient management of container root media with impatiens. J. Amer. Soc. Hort. Sci. 121:442-452.

Argo, W., J.A. Biernbaum, and D.D. Warncke. 1997. Geographical characterization of greenhouse irrigation water. HortTechnology 7:4955.

Bertoni, G.M., A. Pissaloux, P. Morad, and D.R. Sayag. 1992. Bicarbonate-pH relationship with iron chlorosis in white lupine. J. Plant Nutr. 15:1509-1518.

Dell'Orto, M., S. Samti, P. De Nis, S. Cesco, Z. Varanini, G. Zocchi, and R. Pinton. 2002. Development of Fe-deficiency responses in cucumber (Cucumis sativus L.) roots: Involvement of plasma membrane H+-ATPase activity. J. Exp. Bot. 51:695-701.

Fleming, A.L., R.L. Cheney, and B.A. Coulombe 1984. Bicarbonate inhibits Fe-stress response and $\mathrm{Fe}$ uptake-translocation of chlorosis-susceptible soybean cultivars. J. Plant Nutr. 7:699-714.

Havlin, J.L., J.D. Beaton, S.L. Tisdale, and W.L. Nelson. 1999. Soil fertility and fertilizers. Prentice Hall, Upper Saddle River, N.J.

Lang, H.J. 1996. Growing media testing and interpretation. p. 123-140. In: D.W. Reed (ed.). Water, media and nutrition for greenhouse crops. Ball Publishing, Batavia, Ill.

Lang, H.J., C.L. Rosenfield, and D.W. Reed. 1990. Response of Ficus benjamina and Dracaena marginata to iron stress. J. Amer. Soc. Hort. Sci. 115:589-592.
Li, C.-J., X.-P. Zhu, and F.-S. Zhang. 2000. Role of shoot in regulation of iron deficiency responses in cucumber and bean plants. J. Plant Nutr. 23:1809-1818

Lucena, J.L. 2000. Effects of bicarbonate, nitrate and other environmental factors on iron deficiency chlorosis. A review. J . Plant Nutr. 23:1591-1606.

Marschner, H. 1995. Mineral nutrition of higher plants. 2nd ed. Academic, San Diego, Calif.

McCallister, D.L., R.A. Wiese, and N.J. Soleman. 1989. Effect of potassium salts on alleviation of lime-induced chlorosis in soybean. J. Plant Nutr. 12:1153-1174.

Pearce, R.C., Y. Li, and L.P. Bush. 1999a. Calcium and bicarbonate effects on the growth and nutrient uptake of burley tobacco seedlings: Float system. J. Plant Nutr. 22:1079-1090.

Pearce, R.C., Y. Li, and L.P. Bush. 1999b. Calcium and bicarbonate effects on the growth and nutrient uptake of burley tobacco seedlings: Hydroponic culture. J. Plant Nutr. 22:10691078.

Rabotii, G. and G. Zocchi. 1994. Plasma membrane-bound $\mathrm{H}+$-ATPase and reductase activities in $\mathrm{Fe}$-deficient cucumber roots. Physiol. Plant. 90:779-785.

Rosenfield, C.-L., D.W. Reed, and M.W. Kent. 1991. Dependency of iron reduction on development of unique root morphology in Ficus benjamina L. Plant Physiol. 95:11201124.

Schikora, A. and W. Schmidt. 2002. Formation of transfer cells and H+-ATPase expression in tomato roots under $\mathrm{P}$ and $\mathrm{Fe}$ deficiency. Planta 215:304-311

Schmidt, W., J. Tittel, and A. Schikora. 2000. Role of hormones in the induction of iron deficiency responses in Arabidopsis roots. Plant Physiol. 122:1109-1118.

Valdez-Aguilar, L.A. and D.W. Reed. 2007. Response of selected greenhouse ornamental plants to alkalinity in irrigation water. J. Plant Nutr. 30 (in press).

Warncke, D.D. and D.M. Krauskopf. 1983. Greenhouse growth media: Testing and nutrition guidelines. Ext. Bul. E-176. Mich. State Univ. Coop. Ext. Ser., Lansing, Mich.

Whipker, B.E. 2001. Alkalinity control. p. 9-12 In: B.E. Whipker, J.M. Dole, T.J. Cavins, J.L. Gibson, W.C. Fonteno, P.V. Nelson, D.S Pitchay, and D.A. Bailey (eds.). Plant root zone management. North Carolina Flower Growers' Assn, Raleigh., N.C.

Zouari, M., A. Abadía, and J. Abadía. 2001. Iron is required for the induction of root ferric chelate reductase activity in iron-deficient tomato J. Plant Nutr. 24:383-396. 